\title{
Online Geoboard Media Improves Understanding of Two- dimensional Flat Shape Concepts in Elementary School Students
}

\section{Husni Sabil1*, Asrial' ${ }^{2}$, Syahrial ${ }^{3}$, Muhammad Andika Robiansah4, Muhammad Dewa Zulkhi'5, Latipia Damayanti6, Nurul Kiska7, Ninda Silvia ${ }^{8}$, Ubaidillah ${ }^{9}$}

\author{
${ }^{1}$ Matematics Education Study Program, Jambi University, Jambi, Indonesia \\ ${ }^{2}$ Chemistry Education, Jambi University, Jambi, Indonesia \\ ${ }^{3}$ Primary School Teacher Education, Jambi University, Jambi, Indonesia \\ 4,5,6,7,8,9 Elementary school teacher education student, Jambi University, Jambi, Indonesia
}

\section{ART I CLE IN F O}

\section{Article history:}

Received October 02, 2021

Revised October 03, 2021

Accepted November 14, 2021

Available online November 25, 2021

\section{Kata Kunci:}

Geoboard Online, Pemahaman,

Konsep, Matematika

Keywords:

Online Geoboard, Concept

Understanding, Mathematics

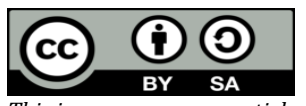

This is an open access article under the CC BY-SA license.

Copyright (C) 2021 by Author. Published by Universitas Pendidikan Ganesha.

\begin{abstract}
A B S T R A K
Dalam pembelajaran matematika 78,5\% siswa belum memahami materi. konsep yang diajarkan oleh guru pada materi geometri. Hal ini disebabkan karena media yang digunakan guru dalam pembelajaran matematika tidak sesuai. Media yang kurang sesuai akan membuat siswa kesulitan dalam memahami materi pembelajaran sehingga berdampak pada hasil belajar siswa yang rendah. Penelitian ini bertujuan untuk menganalisis pengaruh penggunaan Geoboard online dalam meningkatkan pemahaman konsep matematika siswa pada pembelajaran Bangun Datar kelas IV SD. Jenis penelitian Jenis penelitian menggunakan Mix method yaitu pengambilan data menggunakan Kualitatif dan Kuantitatif. Pengambilan sampel menggunakan purposive sampling dengan jumlah 28 siswa. Desain penelitian menggunakan Explanatory Sequential Design. Penelitian ini melibatkan beberapa variabel sebagai kategori penelitian yaitu respon Peserta didik dan Pemahaman Konsep. Analisis data menggunakan statistik deskriptif dan inferensial. Hasil penelitian yaitu variabel dari respon, dan Pemahaman Konsep memiliki pengaruh yang signifikan, dengan nilai sig<0,05 dan pada setiap varibel dominan dalam Kategori baik, Sehingga media online geoboard berpengaruh pada Pemahaman Konsep bangun datar peserta didik. Oleh karena itu, penggunaan media online geoboard dapat dijadikan sebagai alternatif pembelajaran yang menyenangkan dan sesuai untuk usia anak sekolah dasar. Implikasi penelitian ini adalah untuk menggunakan media pembelajaran dalam membantu peserta didik dalam memahami konsep berbasis teknologi.
\end{abstract}

\section{A B S T R A C T}

In learning mathematics, $78.5 \%$ of students do not understand the material concepts taught by the teacher on geometry material. It is because the media used by the teacher in learning mathematics is not appropriate. Inappropriate media will make it difficult for students to understand the learning material, so that it has an impact on low student learning outcomes. This study aims to analyze the effect of using Geoboard online in improving students' understanding of mathematical concepts in the fourth-grade elementary school's Bangun Datar learning. This type of research uses the Mix method, namely data collection using qualitative and quantitative. Sampling using purposive sampling with a total of 28 students. The research design uses Explanatory Sequential Design. This study involves several variables as research categories, namely Student responses and Concept Understanding. Data analysis used descriptive and inferential statistics. The study results are that the variable of response and Concept Understanding has a significant influence, with a value of sig $<0.05$, and on each dominant variable in the excellent category, so that online geoboard media affects students' understanding of the flat wake concept. Therefore, Geoboard online media can be used as an alternative learning that is fun and suiTablefor children in elementary school. The implication of this research is to use learning media in helping students understand technology-based concepts.

\section{INTRODUCTION}

Learning is a process of adding insight, improving skills, and changing attitudes for the better (Lin \& Li, 2018; Rahayu \& Fahmi, 2018). Good learning will produce good quality students too, therefore the learning process continues to be developed (Chabanet et al., 2021; Tongchai, 2016). One of them is learning to use learning media, which can be used as a learning method for elementary school students, because learning while playing can instill character in students who mix and match (Amdany et al., 2018; Huang et al., 2020; Kumala et al., 2020). In learning activities at school, students are taught various subjects according to their level, one of which is mathematics. Mathematics is a lesson given to students ranging from basic 
education to higher education to equip students with the ability to think logically, systematically, logically, creatively, and critically as well as the ability to work together (Baya'a et al., 2019; Klemp, 2019; Turgut \& Turgut, 2018). In primary school education, mastery of mathematical competencies is important because mathematics is always used in everyday life (Lestari et al., 2021; Nurlaily et al., 2019). In particular, the Ministry of National Education stated that the purpose of learning mathematics is to understand mathematical concepts, explain the relationship between concepts, and apply concepts or algorithms (Kenedi et al., 2018; Setyawan \& Simbolon, 2018; Warti, 2018). Understanding includes goals, behaviors, or responses that reflect understanding of written messages contained in a communication. Understanding mathematical concepts is also very important in the learning process, because understanding concepts will make it easier for students to understand learning competencies and so that students have good basic provisions to achieve other basic skills such as reasoning, communication, connection, and problem solving (Agustian et al., 2015; Anjarsari et al., 2020; Pamungkas et al., 2019).

Based on the track record and collaboration with the homeroom teacher in class IVA at SDN 13/1 Muara Bulian. Researchers obtained data on 28 students in learning mathematics, it can be seen that $78.5 \%$ of students did not understand the material. concepts taught by the teacher on geometry material. To help solve these problems, it is necessary to manipulate objects used for learning mathematics which are commonly called media or teaching aids, concrete learning media are needed that can emphasize the importance of real contexts that can provide opportunities for active and creative students. Students will be easier to remember and understand a learning concept if they build their own knowledge through real contexts. The form of concrete media that can be used to improve students' conceptual understanding is Geoboard media. In Learning to Facilitate the Implanting of Mathematical Concepts in the need for Learning Media. Learning media is anything that can be used to convey messages or information in the teaching and learning process so that it can stimulate students' attention and interest in learning, making it easier to instill concepts (Sukmana \& Suartama, 2019; Yuliani et al., 2020). Learning media has many functions in classroom learning, namely making learning more effective and efficient, increasing student interest and motivation, and making students happier and less bored (Kristanto et al., 2021; Nurrohmah et al., 2018). Especially in Mathematics In elementary schools, the importance of media is to convey learning to students because at this time students receive something real and logical (Puspitowati, 2019; Ridha Yoni Astika et al., 2020; Seruni et al., 2020).

Mathematics is a symbolic language that has a practical function to express quantitative and spatial relationships (Baya'a et al., 2019; Klemp, 2019). Mathematics examines abstract objects and their mindset is deductive (Turgut \& Turgut, 2018). Based on the cognitive development of elementary school students at the concrete operational stage, elementary school-aged children generally have difficulty understanding abstract things (Bito \& Fredy, 2020; Nurlaily et al., 2019). Therefore, there is a need for educational media that can bridge children at the concrete operational stage in studying mathematics as an abstract science. Media in learning can be interpreted as a tool or the like that can be used as a messenger in a learning activity (Hertanto, 2021; Suryantari et al., 2019; Wahyuningtyas \& Sulasmono, 2020). One of the important materials that must be mastered in learning mathematics is geometry. (Lutfian, 2016) explains that geometry is very important to learn, Geometry helps humans have a complete appreciation of their world, geometry plays a major role in the field of mathematics.

The use of Geoboard Online media will also increase students' appreciation of the competence of flat building materials and this Geoboard media can be used as a learning medium as well as an interesting educational game (Mayasari et al., 2017; Mudaly \& Sibiya, 2018). Geoboard is a nail board that can be used in learning geometry, this nail board is only made of thin wood and then nailed to this area makes learning more effective. Geoboard is a teaching aid in elementary school that is useful for instilling concepts or understanding of geometry in learning, such as the introduction of flat shapes, introduction of the circumference of flat shapes, and determining or calculating the area of a flat shape. flat shape (Firdayati, 2019; Khotimah \& Hernawati, 2018; Mudaly \& Sibiya, 2018). There are many studies on Learning Media, especially Mathematics. Based on this description, the researcher is interested in conducting research on geoboard online learning media which aims to see "The effect of understanding concepts in Mathematics Learning" (Lastrijanah et al., 2017). The Effect of Geoboard Learning Media on Student Learning Outcomes. The difference between this research and other research is that this research examines technology-based online media, while other studies research media in general. This study aims to analyze the effect of using Geoboard online in improving students' understanding of mathematical concepts in the fourth grade elementary school's Bangun Datar learning. 


\section{METHOD}

This study uses a quantitative and qualitative approach (Mixed Method) if the researcher has questions that need to be tested in terms of the type of research and the process, and involves the combination of quantitative and qualitative methods in one study (Sugiyono, 2013). By using the research design Explanatory Sequential Design, which is a design that implies the collection and analysis of quantitative as the main data and then qualitative data in two successive phases in one study (Sugiyono, 2013). The population in this study is the total number of fourth grade students at SD Negeri 13/I Muara Bulian. The samples used were all fourth grade students of SD N 13/I Muara Bulian, which amounted to 28 students. In determining the sample, a sampling technique was used, namely purposive sampling in which the technique of determining the sample was carried out with certain considerations (Sugiyono, 2013). The criteria applied by the researcher were considerations of the condition of the school and students, the school studied by the researcher. researchers use electronic teaching materials, which makes it easier for the data obtained by researchers to see understanding the concept of flat shapes using geoboard online media.

The research instrument used a questionnaire and interviews. The questionnaire used is a character questionnaire of love for the homeland and love of peace as well as a response questionnaire for the use of online goeboard media. With the number of valid questions each 12 items. As for the reliability is calculated using the Cronbach alpha formula. After the instrument was tested and analyzed for reliability, the reliability coefficient of the response questionnaire was 0.750 and for Concept Understanding was 0.740 , so it could be concluded that the instrument was reliable. The questionnaire uses a Likert scale category with the types of scales strongly agree (SS), agree (S), not sure (N), disagree (TS), and strongly disagree (STS). On each question that has a positive value in the instrument that has a value of: $S S=5, S=$ $4, \mathrm{~N}=3, \mathrm{TS}=2$, and STS $=1$. The score is reversed for the value on the negative item. Questionnaires given to respondents were used to measure quantitative data. The following is a research questionnaire grid in Table1. Interview is a technique of collecting data in the form of information from a resource person, by asking questions and statements The interviews used are short questions, with 15 questions each. The teacher interview grid in Table 2. Interviews were also conducted with students to determine students' responses to the online geoboard media. With the student interview grid in Table 3.

Table 1. Student response questionnaire grid for online geoboard

\begin{tabular}{lllc}
\hline No & \multicolumn{1}{c}{ Aapect of Assessment } & \multicolumn{1}{c}{ Statement } & $\begin{array}{c}\text { Number of } \\
\text { item }\end{array}$ \\
\hline 1 & Easy to understand & Easy to understand & 3 \\
2 & Fun Enthusiasm & Spirit when learning & 3 \\
3 & Clear and structure & Clear pictures and writing & 3 \\
4 & Easy to use & Can be used alone & 3 \\
\hline Total & & & $\mathbf{1 2}$ \\
\hline
\end{tabular}

Table 2. Grid In Teacher Interviews

\begin{tabular}{lllc}
\hline No & assessment aspect & Statement & $\begin{array}{c}\text { number of } \\
\text { questions }\end{array}$ \\
\hline 1 & Media use & Is it easy to use & 5 \\
2 & Student Response & Passion and focus in learning & 5 \\
3 & Result & Increased understanding of concepts & 5 \\
\hline Total & & $\mathbf{1 5}$ \\
\hline
\end{tabular}

Table 3. Grid In Student Interviews

\begin{tabular}{lllc}
\hline No & \multicolumn{1}{c}{ Aspek penilaian } & \multicolumn{1}{c}{ Statement } & $\begin{array}{c}\text { number of } \\
\text { questions }\end{array}$ \\
\hline 1 & understanding & Easy to understand & 3 \\
2 & Fun & Fun and not boring & 3 \\
3 & Clear and Structure & The lines and colors are clear and beautiful & 3 \\
4 & Results after & using & understand the concept of two-dimentional figure \\
& geoboard online & & 3 \\
\hline Total & & $\mathbf{1 2}$ \\
\hline
\end{tabular}


The data collection technique used is quantitative data collection as the main data and is strengthened by qualitative data. Quantitative data is a type of data that can be measured or calculated directly. Existing quantitative data is strengthened by qualitative data generated from interviews. In research, qualitative data is in the form of a description of the object of research. Qualitative data provide and show the quality of the object of research carried out. Data analysis in this study used descriptive statistics and inferential statistics. Descriptive statistical information is statistical information used to analyze data by describing or describing the data collected, without intending to draw conclusions that can be applied generally or generalize (Sugiyono, 2019). This study uses descriptive statistics using the maximum, minimum, mean and standard deviation values. Whereas inferential statistics are statistical calculations used to analyze data from samples and the results will be generalized or concluded for the population from which the sample was taken (Sugiyono, 2019). By using the assumption test, namely normality and linearity tests by taking the results of the sig value decisions on the processed data. And using hypothesis testing, namely regression testing with the provision that if the value of sig < probability 0.005 then there is an effect of one independent variable $(\mathrm{X})$ or more on the dependent variable (Y) or the hypothesis is accepted. If the value of sig $>0.005$ then there is an effect of the independent variable (X) on the dependent variable $(\mathrm{Y})$ or the hypothesis is rejected.

\section{RESULT AND DISCUSSION}

\section{Result}

The questionnaire used in this case is a response to the use of online media for students' geoboards. The results of the response questionnaire on the application of online goeboard media with results of $57.14 \%$ (16 of 28 students) which are included in the very good category, in the good category the results are $35.7 \%$ (10 out of 28 students), in the moderate category the results are 7, 14 (2 out of 28 students) in the bad category obtained results of $3.57 \%$ ( 1 of 28 students) and in the very poor category obtained results of $3.57 \%$ ( 1 person out of 28 students), therefore it can be seen that in The application of the game of hide and seek at SDN 13/1 Muara Bulian is in the very good category. Where this can be seen from the data on the number of students who have filled out a questionnaire containing several questions that have been processed by researchers and produce the data.

The results of the questionnaire on understanding the concept of online geoboard media showed that there were $28.57 \%$ ( 8 of 28 students) who were included in the very good category, in the good category the results were $35.7 \%$ (10 out of 28 students), in the moderate category the results were $21,42 \%$ ( 6 of 28 students) in the bad category obtained results of $10.71 \%$ (3 of 28 students) and in the very bad category obtained results of $3.57 \%$ ( 1 person out of 28 students), so this can be seen from the data the number of students who have filled out a questionnaire containing several questions that have been processed by researchers and produced the data. The resulting data shows the understanding of the online media concept of geoboards in the classroom in the good category. From the ANOVA, it is used to see whether there is a simultaneous influence between the two $\mathrm{X}$ variables on $\mathrm{Y}$. Based on the Tableabove, it can be seen that the significant value is 0.00 where the sig $<0.05$. From the existing sig value in accordance with the decision making, the existing hypothesis is accepted, namely that there is an effect on the variable $\mathrm{X}$ simultaneously on the variable $\mathrm{Y}$.

\section{Discussion}

Learning Media is a tool to support learning (Astuti et al., 2017; Hidayah \& Fathimatuzzahra, 2019; Saputri \& Qohar, 2020). With the existence of learning media, the learning process will be easier (Jannah et al., 2020; Manurung \& Panggabean, 2020; Umarella et al., 2019). One of them is this online geoboard media to make it easier for students to understand in mathematics building lessons (Khotimah \& Hernawati, 2018; Mudaly \& Sibiya, 2018). Not all students can understand concepts quickly because each student has a different cognitive, with this learning media it can help in understanding concepts and become more interesting in learning. Online geoboard media is a media that is in smartphone applications, following the era of technology in education. Technology greatly facilitates human work, one of which is in the field of education, with technology-based learning media, learning will be more effective and students will be more interested in learning (Chen et al., 2019; Churchill et al., 2013; Nagge et al., 2018).

The use of geoboard online learning media in class IV Elementary School 13/I Muara Buliani was given a response questionnaire to see student responses. With the results obtained in the good category, with the results obtained 57,14\% with 16 out of 28 students in the State Elementary School 13/I Muara, this is because the use of online learning media geoboard students are more active in learning, not only have the ability in the realm of cognitive abilities but students will also have affective and psychomotor abilities. The use of geoboard online learning media is considered very suiTablefor the character and age of 
elementary school children. The use of geoboard online learning media in learning is not only on students' cognitive, affective and psychomotor abilities (Khotimah \& Hernawati, 2018; Mudaly \& Sibiya, 2018). By being integrated with online learning media, Concept Understanding can also be measured, in a questionnaire where the results are obtained in a good category, namely $35.7 \%$ with 10 out of 28 students from the State Elementary School 13/I Muara Bulian. Concept understanding is shown by understanding students, being able to explain and compare flat shapes.

In accordance with previous research, using geoboard media to see student learning outcomes (Lastrijanah et al., 2017). The use of geoboard media in blind students (Sundari \& Iswari, 2019). The position of this study is to become a benchmark for the use of online media in learning with previous research, namely examining the influence of online learning media in students' understanding and interest in learning physics concepts. Student responses during learning by integrating learning media obtained good response results, they prefer to do learning by playing. the integration of online goeboard media can also measure students' conceptual understanding in public elementary schools. The novelty in this research is to know the effect of the results of using geoboard online media at the State Elementary School 13/I Muara Bulian. The variables studied are the variables studied, there are 2 variables, namely response and understanding of the concept of using geoboard learning media. This study is to determine the effect of using geoboard online media in public elementary schools on response and understanding.

The implication of the research on Understanding the Flat Shape Concept for Fourth Grade Elementary School Students: Implementation of Geoboard Online Media in Mathematics Learning is that the use of technology-based learning media can make learning easier for both teachers in teaching and students in learning. The limitation of this research is the use of online media for flat-shaped mathematics lessons. The impact for students is to make it easier to understand the concept of flat shape and increase interest and motivation in learning. Recommendations of this research for teachers as educators in the field of education and schools to be able to use online media in learning to measure and determine the response and understanding of students, due to the rapid development of technology in Indonesia to facilitate the teaching and learning process in elementary schools, the use of technology should be maximum.

\section{CONCLUSION}

The use of online geoboard media for understanding the concept of flat shapes has an influence. In this study, the dominant results were in the good category, from the data obtained on the use of online geoboard media in learning. Therefore, the use of geoboard online media can be used as an alternative to fun learning and is appropriate for the age of elementary school children. In addition to making it easier for teachers to introduce hereditary culture, namely games, students are also more active in learning.

\section{REFERENCES}

Agustian, E., Sujana, A., \& Kurniadi, Y. (2015). Pengaruh Pendekatan Open-Ended Terhadap Kemampuan Berpikir Kreatif Matematis Siswa Sekolah Dasar Kelas V. Mimbar Sekolah Dasar, 2(2), 234-242. https://doi.org/10.17509/mimbar-sd.v2i2.1333.

Amdany, P., Sularmi, S., \& Sriyanto, M. I. (2018). Learning Motivation of Slow Learner in Elementary School. Social, Humanities, and Educational Studies (SHEs): Conference Series, 1(1), 613-618. https://doi.org/10.20961/shes.v1i1.23506.

Anjarsari, E., Donny, D. F., \& Abdul, W. A. (2020). Pengembangan Media Audiovisual Powtoon pada Pembelajaran Matematika untuk Siswa Sekolah Dasar. Jurnal Matematika Dan Pendidikan Matematika, 2(2). https://doi.org/10.26594/jmpm.v5i2.2084.

Astuti, I. A. D., Sumarni, R. A., \& Saraswati, D. L. (2017). Pengembangan Media Pembelajaran Mobile Learning Berbasis Android. JPPPF- Jurnal Penelitian Dan Pengembangan Pendidikan Fisika, 3(1), 57-62. https: //doi.org/10.21009/jrpk.072.10.

Baya'a, N., Daher, W., \& Anabousy, A. (2019). The development of in-service mathematics teachers' integration of ICT in a community of practice: Teaching-in-context theory. International Journal of Emerging Technologies in Learning, 14(1), 125-139. https://doi.org/10.3991/ijet.v14i01.9134.

Bito, G. S., \& Fredy. (2020). Ethnomathematics: Musical Instrumen In Ja'i Dances For Culturally Responsive $\begin{array}{lllll}\text { Teaching In Elementary } \quad \text { Schools. } & \text { 183imaryEdu, }\end{array}$ https://doi.org/10.22460/pej.v4i2.1853.

Chabanet, S., El-Haouzi, H. B., \& Thomas, P. (2021). Coupling digital simulation and machine learning metamodel through an active learning approach in Industry 4.0 context. Computers in Industry, 133. https://doi.org/10.1016/j.compind.2021.103529.

Chen, Y., Mayall, H. J., York, C. S., \& Smith, T. J. (2019). Parental perception and English Learners' mobile- 
assisted language learning: An ethnographic case study from a technology-based Funds of Knowledge approach. Learning, Culture and Social Interaction, 22. https://doi.org/10.1016/j.lcsi.2019.100325.

Churchill, D., King, M., \& Fox, B. (2013). Learning design for science education in the 21st century. Zbornik Instituta Za Pedagoska Istrazivanja, 45(2), 404-421. https://doi.org/10.2298/ZIPI1302404C.

Firdayati, L. (2019). Penggunaan Model Elpsa Dengan Bantuan Alat Peraga Geoboard Pada Materi Bangun Datar Segi Empat. Jurnal Aksioma, 8(1). https://doi.org/10.24127/ajpm.v8i1.1767.

Hertanto, D. B. (2021). Upaya Peningkatan Kualitas Kuliah Jaringan Komputer melalui Penerapan Media Pembelajaran Packet Tracer 5.0. Jurnal Pendidikan Teknologi Dan Kejuruan Dan Kejuruan, 20(1). https://doi.org/10.21831/jptk.v20i1.7753.

Hidayah, I. N., \& Fathimatuzzahra. (2019). Development of Math Comic Learning Media on the Subject of Algebraic Expressions for Seventh Grade of Junior High School Students. Journal of Physics: Conference Series, 1227(1). https://doi.org/10.1088/1742-6596/1227/1/012029.

Huang, S.-Y., Kuo, Y.-H., \& Chen, H.-C. (2020). Applying Digital Escape Rooms Infused with Science Teaching in Elementary School: Learning Performance, Learning Motivation, and Problem-Solving Ability. Journal Pre-Proof, 1(1), 1-46. https://doi.org/10.1016/j.tsc.2020.100681.

Jannah, I. N., Prasetiyawati, D., Hariyanti, D., \& Prasetyo, S. A. (2020). Efektivitas Penggunaan Multimedia dalam Pembelajaran IPA di SD. 4(1), 54-59.

Kenedi, A. K., Hendri, S., Ladiva, H. B., \& Nelliarti. (2018). Kemampuan Koneksi Matematis Siswa Sekolah Dasar Dalam Memecahkan Masalah Matematika. Jurnal Numeracy, 5(2), 226-235. https://doi.org/10.46244/numeracy.v5i2.396.

Khotimah, H., \& Hernawati, H. (2018). Komparasi Hasil Belajar Siswa Menggunakan Geoboard dan Geopuzzle Pada Materi Segiempat dan Segitiga Kelas VII SMP. JTAM (Jurnal Teori Dan Aplikasi Matematika), 2(2). https://doi.org/10.31764/jtam.v2i2.714.

Klemp, T. (2019). Early mathematics-teacher communication supporting the pupil's agency. International Journal of Primary, Elementary and Early Years Education, 1-14. https://doi.org/10.1080/03004279.2019.1663893.

Kristanto, A., Sulistiowati, ., \& Pradana, H. D. (2021). Brain-Based Online Learning Design in The Disruptive Era for Students in University. Journal of Educational and Social Research, 11(6), 277. https://doi.org/10.36941/jesr-2021-0147.

Kumala, F. N., Setiawan, D. A., \& Shaleha, P. R. (2020). Contextual-Based Animal Encyclopedia: HOTS on Elementary School's Students. 2nd International Conference on Education and Social Science Research (ICESRE 2019) Contextual-Based, 417(Icesre 2019), 132-137. https://doi.org/10.2991/assehr.k.200318.025.

Lastrijanah, L., Prasetyo, T., \& Mawardini, A. (2017). Pengaruh Media Pembelajaran Geoboard Terhadap Hasil Belajar Siswa. DIDAKTIKA TAUHIDI: Jurnal Pendidikan Guru Sekolah Dasar, 4(2).

Lestari, F. P., Ahmadi, F., \& Rochmad, R. (2021). The Implementation of Mathematics Comic Through Contextual Teaching and Learning to Improve Critical Thinking Ability and Character. European Journal of Educational Research, 10(1), 497-508. https://doi.org/10.12973/EU-JER.10.1.497.

Lin, L., \& Li, M. (2018). Optimizing learning from animation: Examining the impact of biofeedback. Learning and Instruction, 55. https://doi.org/10.1016/j.learninstruc.2018.02.005.

Manurung, S. R., \& Panggabean, D. D. (2020). Improving students' thinking ability in physics using interactive multimedia based problem solving. Cakrawala Pendidikan. https://doi.org/10.21831/cp.v39i2.28205.

Mayasari, N., P, N. I., Novianti, D. E., Indriani, A., \& Noeruddin, A. (2017). Pemanfaatan Media Pembelajaran Geoboard Dalam Pembelajaran Matematika Materi Keliling Dan Luas Bangun Segi Empat Dan Segitiga. J-ABDIPAMAS (Jurnal Pengabdian Kepada Masyarakat), 1(1), 60-65.

Mudaly, V., \& Sibiya, M. (2018). the Effects of the Geoboard on Learner Understanding of Geometry Theorems. PONTE International Scientific Researchs Journal, 74(11). https://doi.org/10.21506/j.ponte.2018.11.8.

Nagge, J. J., Killeen, R., \& Jennings, B. (2018). Using a course pilot in the development of an online problembased learning (PBL) therapeutics course in a post-professional PharmD program. Currents in Pharmacy Teaching and Learning, 10(2), 231-234. https://doi.org/10.1016/j.cptl.2017.10.005.

Nurlaily, V. A., Soegiyanto, H., \& Usodo, B. (2019). Elementary school teacher's obstacles in the implementation of problem-based learning model in mathematics learning. Journal on Mathematics Education, 10(2), 229-238. https://doi.org/10.22342/jme.10.2.5386.229-238.

Nurrohmah, F., Putra, F. G., \& Farida, F. (2018). Development of Sparkol Video Scribe Assisted Learning Media. Formatif: Jurnal Ilmiah Pendidikan MIPA, 8(3), 233-250. https://doi.org/10.30998/formatif.v8i3.2613. 
Pamungkas, D., Mawardi, \& Astuti, S. (2019). Peningkatan Keterampilan Berpikir Kritis dan Hasil Belajar Matematika Pada Siswa Kelas 4 Melalui Penerapan Model Problem Based Learning. Jurnal Ilmiah Sekolah Dasar, 3(2), 212-219. https://doi.org/10.31004/basicedu.v3i1.98.

Puspitowati, P. (2019). Penerapan Model Pembelajaran Berbasis Pengalaman (Experiential Learning) dengan Menggunakan Media Gambar dalam Pembelajaran Menulis Karangan Deskripsi pada Siswa Kelas IV MI Riyadlatul Uqul. Linguista: Jurnal Ilmiah Bahasa, Sastra, Dan Pembelajarannya, 3(2), 120. https://doi.org/10.25273/linguista.v3i2.5734.

Rahayu, E., \& Fahmi, S. (2018). Efektivitas penggunaan model problem based Learning (PBL) dan inkuiri terhadap hasil belajar matematika siswa SMP N 1 Kasihan Kabupaten Bantul semester genap tahun ajaran 2017/2018. JURING (Journal for Research in Mathematics Learning), 1(2), 147. https://doi.org/10.24014/juring.v1i2.5671.

Ridha Yoni Astika, Bambang Sri Anggoro, \& Siska Andriani. (2020). Pengembangan Video Media Pembelajaran Matematika Dengan Bantuan Powtoon. Jurnal Pemikiran Dan Penelitian Pendidikan Matematika (JP3M), 2(2), 85-96. https://doi.org/10.36765/jp3m.v2i2.29.

Saputri, R. R., \& Qohar, A. (2020). Development of Comic-Based Mathematics Learning Media on Social Arithmetic Topic. Journal of Physics: Conference Series, 1657, 012082. https://doi.org/10.1088/1742-6596/1657/1/012082.

Seruni, R., Munawaroh, S., Kurniadewi, F., \& Nurjayadi, M. (2020). Implementation of E-module flip PDF professional to improve students' critical thinking skills through problem based learning. Journal of Physics: Conference Series, 1521(4), 1-6. https://doi.org/10.1088/1742-6596/1521/4/042085.

Setyawan, A. A., \& Simbolon, D. (2018). Pengaruh Kecerdasan Emosional Terhadap Hasil Belajar Matematika Siswa Sekolah Dasar. JPPM (Jurnal Penelitian Dan Pembelajaran Matematika), 1(1). https://doi.org/10.30870/jppm.v11i1.2980.

Sugiyono. (2013). Metode Penelitian Kuantitatif Kualitatif dan R\&D. Cetakan ke-18. CV Alfabeta.

Sugiyono. (2019). Metode Penelitian Kualitatif. Alfabeta.

Sukmana, A. I. W. I. Y., \& Suartama, I. K. (2019). Pengembangan Mobile Learning Berorientasi Model Pembelajaran Flipped Classroom Pada Mata Kuliah Multimedia. Journal of Education Technology, 2(1), 45. https://doi.org/10.23887/jet.v2i1.13808.

Sundari, S. P., \& Iswari, M. (2019). Meningkatkan Kemampuan Menghitung Keliling Bangun Datar melalui Media Geoboard bagi Anak Tunanetra. 212-218.

Suryantari, N. M. A., Pudjawan, K., \& Wibawa, I. M. C. (2019). Pengaruh Model Pembelajaran Inkuiri Terbimbing Berbantuan Media Benda Konkret Terhadap Sikap Ilmiah dan Hasil Belajar IPA. International Journal of Elementary Education, 3(3), 316-326. https://doi.org/10.23887/ijee.v3i3.19445.

Tongchai, N. (2016). Impact of self-regulation and open learner model on learning achievement in blended learning environment. International Journal of Information and Education Technology, 6(5). https://doi.org/10.7763/IJIET.2016.V6.711.

Turgut, S., \& Turgut, I. G. (2018). The effects of cooperative learning on mathematics achievement in Turkey: A meta-analysis study. International Journal of Instruction, 11(3), 663-680. https: //doi.org/10.12973/IJI.2018.11345A.

Umarella, S., Rahmawati, A., \& Susilowati, N. E. (2019). Interactive multimedia lectora inspire based on problem based learning: development in the optical equipment. In Journal of Physics: Conference Series, 1155(1). https://doi.org/10.1088/1742-6596/1155/1/012011.

Wahyuningtyas, R., \& Sulasmono, B. S. (2020). Pentingnya Media dalam Pembelajaran Guna Meningkatkan Hasil Belajar di Sekolah Dasar. Edukatif: Jurnal Ilmu Pendidikan, 2(1), 23-27. https://doi.org/10.31004/edukatif.v2i1.77.

Warti, E. (2018). Pengaruh Motivasi Belajar Siswa terhadap Hasil Belajar Matematika Siswa di SD Angkasa 10 Halim Perdana Kusuma Jakarta Timur. Mosharafa: Jurnal Pendidikan Matematika, 5(2), 177185. https://doi.org/10.31980/mosharafa.v5i2.273.

Yuliani, F., Herman, \& Tarmizi, P. (2020). Pengaruh Model Discovery Learning Berbantuan Media Pop-Up Book terhadap Hasil Belajar Tematik Siswa Kelas IV SD Gugus X Kota Bengkulu. Jurnal Riset Pendidikan Dasar, 3(1), 1-8. https://doi.org/10.33369/juridikdas.3.1.1-8. 